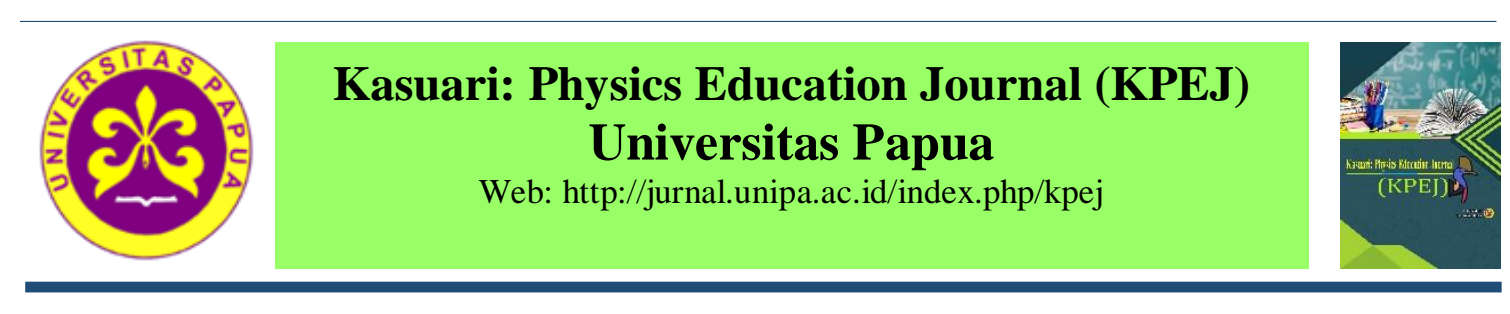

\title{
Effect of Cooperative Learning Model Types of Stick Talking Using Simple Props to Higher Order Thinking Skill
}

\author{
Halimatussa'diyah, Mujasam, Sri Wahyu Widyaningsih* \& Irfan Yusuf \\ Pendidikan Fisika, Fakultas Keguruan dan Ilmu Pendidikan, Universitas Papua \\ *Corresponding Author: s.widyaningsih@unipa.ac.id
}

\begin{abstract}
This study was conducted to see the effect of the talking stick type of learning model by using simple teaching aids on high-level thinking skills in light material in the SMP Yapis Manokwari. Research subjects amounted to 56 students consisting of control class (class VIIIb) totaling 28 students and experimental class (class VIIIa) totaling 28 students. This type of research is quasi-experimental design with non equivalent control group design. The results showed that the data analyzed were normally distributed and homogeneous so that the hypothesis test used independent sample t-test with a significance value $=0.05$. The calculation result with sig 2 tailed is $0,000<=0,05$ so $\mathrm{HO}$ is rejected and $\mathrm{Ha}$ is accepted. This means that there are influences of hots on students who are taught using cooperative learning model type talking stick with those taught using conventional models. In addition, the cooperative learning model type talking stick and conventional models also have an influence on students' hots with different sizes. The difference is seen in the results of the calculation of the $\mathrm{N}$-gain value shows that the $\mathrm{N}$ gain test of the experimental class and the control class are 0.39 and 0.38 respectively in the medium criteria. The $N$-gain value of the postest hots in the experimental and control classes is also 0.40. So that the experimental class and controls increase higher order thingking skill. But the posttest value in the experimental class is better than the control class.
\end{abstract}

Keywords: Simple Props, Higher Order Thiking Skill, Talking Stick.

\section{Pengaruh Model Pembelajaran Kooperatif Tipe Talking Stick Menggunakan Alat Peraga Sederhana terhadap Keterampilan Berpikir Tingkat Tinggi}

\begin{abstract}
Abstrak: Penelitian ini bertujian untuk melihat pengaruh model pembelajaran kooperatif tipe talking stick dengan menggunakan alat peraga sederhana terhadap keterampilan berpikir tingkat tinggi pada materi cahaya kelas VIII SMP Yapis Manokwari. Subyek peneltian berjumlah 56 peserta didik yang terdiri dari kelas kontrol (kelas VIIIb) berjumlah 28 peserta didik dan kelas eksperimen (kelas VIIIa) berjumlah 28 peserta didik. Jenis penelitian ini yaitu quasi eskperimen design dengan desain non equivalent control group design. Hasil penelitian menunjukkan bahwa data yang dianalisis terdistribusi normal dan homogen sehingga uji hipotesisnya menggunakan uji independent sample t-test dengan nilai signifikansi $\alpha=0,05$. Hasil perhitungan dengan sig 2 tailed sebesar $0,000<\alpha=0,05$ sehingga $\mathrm{H}_{0}$ ditolak dan $\mathrm{H}_{\mathrm{a}}$ diterima. Hal ini berarti bahwa terdapat pengaruh hots pada peserta didik yang diajarkan menggunakan model pembelajaran kooperatif tipe talking stick dengan yang diajar menggunakan model konvensional. Selain itu, model pembelajaran kooperatif tipe talking stick dan model konvensional juga memiliki pengaruh terhadap hots peserta didik dengan besar yang berbeda. Perbedaan tersebut dilihat pada hasil perhitungan nilai N-gain menunjukkan bahwa uji $\mathrm{N}$-gain kelas eksperimen dan kelas kontrol berturut-turut 0,39 dan 0,38 dalam kriteria sedang. Nilai $\mathrm{N}$-gain postest hots pada kelas eksperimen dan kontrol juga sebesar 0,40. Sehingga kelas eksperimen dan kontrol meningkatkan hots. Tetapi nilai postest pada kelas eksperimen lebih baik dibandingkan kelas kontrol.
\end{abstract}

Kata kunci: Alat Peraga Sederhana, Berpikir Tingkat Tinggi, Pembelajaran Kooperatif Tipe Talking Stick 


\section{PENDAHULUAN}

Pendidikan merupakan salah satu faktor yang sangat penting, kemajuan suatu bangsa sangat ditentukan oleh kemajuan kemajuan bangsa itu sendiri, era globalisasi yang terjadi saat ini membawa dampak yang sangat besar bagi masyarakat Indonesia terutama mengenai pendidikan karakter bangsa Misrawati, (2017: 66). Oleh sebab itu, pendidikan juga dapat diartikan mempunyai peran penting dalam meningkatkan kualitas sumber daya manusia di seluruh dunia yaitu untuk mencerdaskan kehidupan bangsa, kreatif, dan dapat bertanggung jawab. Pendidikan juga merupakan kebutuhan yang sangat menunjang dalam segala aspek-aspek kehidupan. Komponen-komponen dalam tujuan pembelajaran yang ingin dicapai peneliti yaitu didalam kelas peserta didik yang akan memainkan peranan ketika proses pembelajaran, tujuan pembelajaran yang ingin dicapai, jenis-jenis kegiatan yang akan dilakukan di dalam kelas dan metode pembelajaran yang akan digunakan.

Menurut (Depdiknas, 2007), diuraikan bahwa: "pembelajaran yaitu suatu proses interaksi peserta didik dengan guru dan sumber belajar dalam suatu lingkungan belajar. Proses pembelajaran harus direncanakan, dilaksanakan, dinilai, dan diawasi. Pelaksanaan pembelajaran merupakan pelaksanaan dari rencana pelaksanaan pembelajaran (RPP). Implementasi pembelajaran meliputi kegiatan pendahuluan, kegiatan inti dan kegiatan penutup." Mata pelajaran IPA khususnya mata pelajaran fisika merupakan salah satu mata pelajaran yang di pelajari di sekolah menengah pertama (SMP), pengertian fisika yaitu ilmu pengetahuan yang didalamnya mempelajari fenomena alam yang terjadi di alam semesta. Tujuan dalam mempelajari fisika yaitu agar peserta didik dapat mengetahui interaksi antar suatu benda, dan dapat mengetahui fenomena yang terjadi di alam sekitar.

SMP Yapis Manokwari merupakan salah satu sekolah swasta yang terletak di Papua Barat. SMP Yapis Manokwari juga merupakan salah satu sekolah yang melaksanakan proses pembelajaran menggunakan KTSP. Penerapan KTSP dan silabus juga mengacu pada kompetensi yang harus dicapai peserta didik. Sistem pelaksanaan pembelajaran juga harus berorientasi pada optimalisasi dari diri peserta didik. Esensi KTSP juga bersifat multimedia dan student center, dan juga diharapkan mampu menciptakan peserta didik menjadi lebih aktif, kritis, mandiri dan kreatif dalam melakukan berbagai pengalamanpengalaman belajar menurut Djamas (2011: 343), masalah-masalah yang peneliti alami selama PPL di SMP Yapis Manokwari yaitu keterampilan berfikir tingkat tinggi pada peserta didik masih sangat kurang khususnya pada mata pelajaran fisika. Guru cenderung hanya memberikan soal-soal kepada peserta didik pada tahapan mengingat (C1), memahami (C2) dan menerapkan $\left(\mathrm{C}_{3}\right)$ dan kurang melatih peserta didik untuk mengerjakan soal-soal menganalisis $\left(\mathrm{C}_{4}\right)$, mengevaluasi $\left(\mathrm{C}_{5}\right)$, dan menciptakan $\left(\mathrm{C}_{6}\right)$.

Keterampilan berpikir tingkat tinggi awalnya telah dimiliki oleh peserta didik meskipun harus didorong agar dapat mencapai tingkat yang lebih baik, oleh sebab itu, guru berperan penting untuk membimbing peserta didik secara rutin untuk melakukan latihan-latihan soal Higer Order Thinking Skills (HOTS) seperti soal essay, soal pilihan ganda dan lain sebagainya, dengan begitu kemampuan yang dimiliki peserta didik dapat 
berkembang. Hal ini selaras dengan pernyataan Yusuf \& Widyaningsih (2018: 43-44) menyatakan bahwa soal-soal keterampilan berpikir tingkat tinggi juga dapat disajikan dalam bentuk soal pilihan ganda, essay dan lain sebagainya, oleh sebab itu, perlu dilakukan penelitian mengenai keterampilan berpikir tingkat tinggi disekolah. Menurut Arifin \& Retnawati (2017: 99) menyatakan bahwa Agar HOTS peserta didik dapat berkembang dengan baik, maka siswa perlu dibiasakan dengan aktivitas-aktivitas yang melatih HOTS itu sendiri.

Peneliti juga mengamati ketika guru mengajar di kelas masih menggunakan model pembelajaran langsung, tidak hanya itu dengan menggunakan model pembelajaran langsung peserta didik juga cenderung di dalam kelas kurang aktif. Model pembelajaran yang guru gunakan didalam ruangan cenderung kurang menarik sehingga peserta didik juga akan merasa jenuh, dan bosan saat belajar fisika. Guru diharapkan dapat menggunakan model pembelajaran yang dapat menciptakan suasana belajar yang membuat peserta didik lebih aktif, karena dengan menggunakan model pembelajaran yang tepat peserta didik mampu mengikuti proses pembelajaran dengan nyaman. Rendahnya kemampuan berfikir tingkat tinggi pada peserta didik dapat dipengaruhi dengan model pembelajaran yang digunakan guru ketika didalam kelas (ruangan).

Penerapan model pembelajaran kooperatif pada peserta didik akan lebih aktif ketika didalam kelas, dapat meningkatkan kemampuan berfikir antara individu dengan kelompok, dan dapat menumbuhkan sikap menerima kekurangan dari diri sendiri. Menurut Sanjaya (2008) pembelajaran kooperatif juga salah satu yang dapat merealisasikan kebutuhan peserta didik dalam belajar berpikir, memecahkan masalah, dan mengintegrasikan pengetahuan dengan keterampilan. Model pembelajaran kooperatif tipe talking stick merupakan salah satu model pembelajaran yang tepat untuk memecahkan permasalahan di atas, dengan menggunakan model pembelajaran kooperatif tipe talking stick dan bantuan alat peraga sederhana membuat peserta didik lebih aktif dan dapat menumbuhkan keterampilan berfikir tingkat pada peserta didik (HOTS).

Alat peraga sederhana adalah suatu media yang digunakan untuk membantu guru agar proses pembelajaran didalam kelas lebih efektif dan efisien, dengan menggunakan alat peraga sederhana juga dapat merangsang imajinasi peserta didik. Hal ini sejalan dengan Widyaningsih (2011: 301) Alat peraga sederhana juga dapat dibuat dengan cara memanfaatkan barang-barang yang sudah tidak digunakan bahkan dengan memanfaatkan benda-benda sederhana yang ada dilingkungan, dengan demikian kendala biaya dan pengadaan barang yang membutuhkan waktu lama dapat teratasi dan peserta didik bisa mendapatkan membelajaran yang lebih efektif dan efisian.

Upaya-upaya yang dilakukan seorang guru dalam mengatasi rendahnya keterampilan berfikir tingkat tinggi (HOTS) pada peserta didik di SMP Yapis Manokwari yaitu dengan cara merubah model pembelajaran yang akan pakai guru pada saat proses pembelajaran berlangsung. Oleh sebab itu, peneliti lebih memilih model pembelajaran kooperatif tipe talking Stick dalam penelitian ini.

Berdasarkan hasil wawancara dengan guru IPA pada mata pelajaran fisika penjelasan materi membutuhkan waktu hingga beberapa kali pengulangan agar peserta didik dapat 
menerima dan memahami informasi yang diberikan terkait materi yang disampaikan oleh guru.

Tabel 1. Langkah-langkah Pembelajaran Kooperatif

\begin{tabular}{|c|l|}
\hline Kegiatan & \multicolumn{1}{|c|}{ Langkah-langkah Pembelajaran Kooperatif } \\
\hline Pendahuluan & Menyampaikan tujuan dan memberi motivasi \\
\hline \multirow{2}{*}{ Inti } & Menyajikan informasi kepada peserta didik \\
\cline { 2 - 2 } & Membagi peserta didik dalam beberapa kelompok \\
\cline { 2 - 2 } & Membimbing kelompok belajar saat diberikan tugas \\
\hline \multirow{2}{*}{ Penutup } & Mengevaluasi \\
\cline { 2 - 2 } & Memberi penghargaan kepada peserta didik \\
\hline
\end{tabular}

(Nurlailah \& Buditjahjanto, 2013: 698-706)

Dari permasalahan tersebut, jenis penelitian yang peneliti lakukan yaitu quasi eksperimen dengan desain non equivalent control grup design, dengan judul penelitian"Pengaruh Model Pembelajaran Kooperatif Tipe Talking Stick Menggunakan Alat Peraga Sederhana Terhadap Keterampilan Berpikir Tingkat Tinggi Materi Cahaya Kelas VIII SMP Yapis Manokwari". Penelitian ini bertujuan untuk Tujuan penelitian ini untuk mendapatkan pengaruh model pembelajaran kooperatif tipe talking stick dengan penggunaan alat peraga sederhana terhadap keterampilan berfikir tingkat tinggi (HOTS) di kelas VIII di SMP Yapis Manokwari.

\section{METODE PENELITIAN}

Penelitian ini dilakukan di SMP Yapis Manokwari dikelas VIII tahun ajaran 2017/2018. Jenis penelitian yang peneliti lakukan yaitu quasi eksperimen dengan desain non equivalent control grup design. Kelas yang digunakan terdiri dari 2 kelas dengan jumlah 56 peserta didik. Sampel penelitian ditentukan dengan teknik sampling jenuh yaitu semua populasi dijadikan sampel, sehingga diperoleh dua kelas yang masingmasing kelas merupakan kelas eksperimen (menggunakan model pembelajaran kooperatif talking stick) dan kelas kontrol (menggunakan model pembelajaran konvensional), maka diperoleh kelas $\mathrm{VIII}^{\mathrm{A}}$ sebagai kelas eksperimen yang berjumlah 28 peserta didik dan kelas VIII ${ }^{\mathrm{B}}$ sebagai kelas kontrol berjumlah 28 peserta didik.

Teknik analisis data pada penelitian ini menggunakan uji validitas item digunakan untuk melihat tingkat kevalidan suatu item tes menurut Arikunto, (2013: 93)

$$
r_{x p b i}=\frac{M_{p}-M_{c}}{S D_{t}} \sqrt{\frac{p}{q}}
$$

Uji reliabilitas digunakan untuk menguji cobakan instrumen hanya sekali saja, kemudian data yanag diperoleh akan dianalisis dengan teknik-teknik tertentu. Hasil analisis dapat digunakan untuk memprediksi reliabilitas instrumen, pengujian data ini akan dilakukan dengan cara teknik belah dua dari Spearman Brown (Split half) menurut Sugiyono (2015).

$$
r_{i}=\frac{2 r_{b}}{1+r_{b}}
$$


Uji homogenitas digunakan untuk mengetahui homogen tidaknya variansi sampel berawal dari kondisi yang sama, uji homogenitas juga menggunakan softwere (SPSS), penelitian ini dinyatakan homogen apabila nila sig $>0,05$ dan apabila data sig $<0,05$ tidak homogen menurut Pramesti (2014). Uji normalitas digunakan untuk menguji data pada setiap variabel yang akan dianalisis membentuk distribusi normal. Mendeteksi normalitas teknik pengujiannya menggunakan softwere (SPSS), untuk melihat hasil normalitas data kelas eksperimen dan kelas kontrol, kedua kelas dinyatakan terdistribusi normal apabila sig $>0,05$ dan sig $<0,05$ tidak terdistribusi normal menurut Pramesti (2014).

Uji N-Gain digunakan untuk mengetahui pretest dan posttest dilakukan pada awal dan akhir proses pembelajaran yang bertujuan untuk mengetahui kemampuan sebelum dan sesudah diberikan perlakuan menurut Diani, dkk, (2018: 31-44).

$$
g=\frac{S_{\text {post }}-S_{\text {pre }}}{S_{\text {maks }}-S_{\text {Pre }}}
$$

\section{HASIL DAN PEMBAHASAN}

Berdasarkan hasil perhitungan uji validitas item dengan 15 item soal adalah pertanyaan (soal) yang masuk dalam kategori rendah berjumlah empat soal, soal yang termasuk dalam kategori sedang berjumlah delapan soal, soal yang temasuk dalam kategori tinggi berjumlah satu soal dan soal yang tidak valid berjumlah dua soal. Soal nomor 10 dan 15 tidak digunakan dalam penelitian karena kedua soal tidak valid. Hal ini sejalan dengan penelitian Alpusari (2014: 110) menyatakan bahwa soal yang valid, bisa digunakan soalnya untuk tes hasil belajar, sedangkan butir soal yang tidak valid maka soal tidak bisa digunakan atau dibuang.

Uji reliabilitas digunakan untuk melihat reliabilitas intrumen yang telah dianalisis dengan menggunakan aplikasi SPSS versi 2.0 pengujian data ini juga dilakukan dengan cara teknik belah dua dari Spearman Brown (split half). Adapun hasil analisis data yaitu berdasarkan hasil analisis soal diketahui bahwa untuk bagian pertama yaitu 0,587 yang terdiri atas butir soal nomor 1 sampai 8 dan untuk bagian kedua yaitu -0,292 yang terdiri atas butir soal nomor 10 dan 15 . Kemudian peneliti akan membandingkan dengan nilai $r_{\text {tabel }}=0,259$ dengan taraf signifikansi 0,05 , sehingga dapat dilihat untuk nilai reliabilitas yang pertama menunjukkan bahwa $r_{\text {hitung }}=0,587$ lebih besar dari pada nilai $r_{\text {tabel }}=0,259$ dan bagian yang kedua menunjukkan bahwa $r_{\text {hitung }}=-0,292$ lebih kecil dari pada $r_{\text {tabel }}=0,259$.

Korelasi antara bagian pertama dan kedua adalah 0,414 dan guttman split half adalah 0,529. Hasil koefisien reliabilitas Spearman Brown adalah sebesar 0,586 kemudian hasil tersebut dibandingkan dengan $r_{\text {tabel }}=0,259$ dengan taraf signifikansi 0,05 sehingga $t_{\text {hitung }}=0,586$ lebih besar dari pada $r_{\text {tabel }}=0,259$, dengan demikian instrumen ini memiliki koefisien korelasi reliabilitas pada kriteria sedang.

Uji normalitas digunakan untuk melihat apakah suatu data dari sampel terdistribusi normal atau tidak. Uji normalitas digunakan pada kelas eksperimen dan kelas kontrol. Hasil uji normalitas dapat dilihat pada Tabel 2. 
Tabel 2. Uji Normalitas

\begin{tabular}{|c|c|c|c|c|}
\hline \multicolumn{5}{|c|}{ Tests of Normality } \\
\hline \multirow{2}{*}{\multicolumn{2}{|c|}{ Kelas }} & \multicolumn{3}{|c|}{ Kolmogorov-Smirnov ${ }^{\mathrm{a}}$} \\
\hline & & Statistic & Df & Sig. \\
\hline & Eksperimen & 0,163 & 28 & 0,056 \\
\hline & Kontrol & 0,164 & 28 & 0,052 \\
\hline \multicolumn{5}{|c|}{ a. Lilliefors Significance Correction } \\
\hline
\end{tabular}

Hasil uji normalitas menunjukkan bahwa data kemampuan berpikir tingkat tinggi (hots) hasil belajar dari kelas eksperimen dan kelas kontrol memiliki signifikan kolmogorovsmirnov $^{a}$ lebih besar dari $\alpha=0,05$ berarti data tersebut terdistribusi normal.

Menguji homogenitas menggunakan uji homogeneity of variances dari program SPSS dengan taraf signifikan 0,05. Hasil uji homogenitas dapat dilihat pada Tabel 3.

Tabel 3. Uji Homogenitas

\begin{tabular}{|l|c|c|c|}
\hline \multicolumn{4}{|c|}{ Test of Homogeneity of Variances } \\
\hline Posttest \\
\hline Levene Statistic & df1 & df2 & Sig. \\
\hline 0.054 & 1 & 54 & 0,817 \\
\hline
\end{tabular}

Data kemampuan berpikir tingkat tinggi untuk hasil belajar untuk kelas eksperimen dan kontrol memiliki nilai signifikansi 0,817 . Nilai signifikansi tersebut lebih besar dari $\alpha=$ 0,05 yang berarti data dari kedua kelas homogen.

Uji N-Gain digunakan untuk melihat peningkatan keterampilan berpikir tingkat tinggi peserta didik dapat dilihat pada hasil uji $\mathrm{N}$-gain. Hasil uji $\mathrm{N}$-gain untuk kelas eksperimen lebih besar dari pada kelas kontrol, dimana nilai $\mathrm{N}$-gain pada kelas eksperimen 0,39 sedangkan nilai $\mathrm{N}$-gain pada kelas kontrol 0,38 . kedua nilai $\mathrm{N}$-gain pada kedua kelas tersebut tergolong dalam kriteria sedang. Nilai N-gain postest HOTS pada kelas eksperimen dan kontrol sebesar 0,40. Nilai N-gain tersebut memiliki arti model kooperatif tipe talking stick dengan menggunakan alat peraga sederhana memberikan pengaruh terhadap keterampilan berpikir tingkat tinggi. Hal ini sejalan dengan penelitian Rahmawati (2016: 3-4) menyatakan bahwa pada perhitungan nilai N-Gain kelas eksperimen lebih besar dari kelas kontrol maka dapat disimpulkan terdapat pengaruh hasil belajar pada peserta didik.

Uji analisis HOTS Peserta didik, Hasil belajar pretes dan posttest dari kedua kelas memiliki nilai yang berbeda, hasil belajar pretes dan posttest untuk kelas eksperimen memiliki nilai 63 dan 75, sedangkan hasil belajar pretes dan posttest untuk kelas kontrol memiliki nilai 35 dan 45, maka dapat disimpulkan dari hasil belajar pretes dan posttest dari kedua kelas yaitu hasil belajar untuk kelas ekperimen lebih tinggi dari kelas kontrol, sehingga terbukti bahwa dengan menggunakn model pembelajaran kooperatif tipe talking stick dapat meningkatkan hasil belajar peserta didik. 


\section{Pengujian Hipotesis}

Uji Hipotesis Jika data terdistribusi normal dan homogen, maka selanjutnya akan dilakukan uji independent sample t-test dengan menggunakan SPSS dengan taraf signifikan 0,05. Hasil analisis uji hipotesis menunjukkan bahwa hasil analisis hipotesis terdistribusi normal dan homogen sehingga peneliti menggunakan uji independent sample t-test dengan nilai signifikansi $\alpha=0,05$. Pengambilan keputusan dari hasil perhitungan sig 2-tailed sebesar 0,000, sehingga nilai sig 2-tailed $0,000<\alpha=0,05$ maka dapat disimpulkan bahwa $\mathrm{H}_{0}$ ditolak dan $\mathrm{H}_{\mathrm{a}}$ diterima. Hal ini berarti bahwa terdapat pengaruh HOTS pada peserta didik yang diajarkan menggunakan model pembelajaran kooperatif tipe talking stick dengan yang diajar menggunakan model konvensional. Selain itu, model pembelajaran kooperatif tipe talking stick dan model konvensional juga memiliki pengaruh terhadap hots peserta didik dengan besar yang berbeda. Hal ini selaras dengan (Pangkali, Sinon \& Widyaningsih, 2016: 178) menyatakan bahwa hasil uji independent simple t-test dengan taraf sig $<0,05$ nilai $t_{\text {hitung }}>\mathrm{t}_{\text {tabel }}$ maka $\mathrm{H}_{0}$ ditolak, maka terdapat perbedaan hasil belajar peserta didik antara kelas kontrol dan kelas eksperimen.

\section{Pembahasan Hasil Penelitian}

Hasil uji reliabilitas, berdasarkan hasil analisis soal diketahui bahwa untuk bagian pertama yaitu 0,587 yang terdiri atas butir soal nomor 1 sampai 8 dan untuk bagian kedua yaitu -0,292 yang terdiri atas butir soal nomor 10 dan 15 . Kemudian peneliti akan membandingkan dengan nilai $r_{\text {tabel }}=0,259$ dengan taraf signifikansi 0,05 , sehingga dapat dilihat untuk nilai reliabilitas yang pertama menunjukkan bahwa $r_{\text {hitung }}=0,587$ lebih besar dari pada nilai $r_{\text {tabel }}=0,259$ dan bagian yang kedua menunjukkan bahwa $r_{\text {hitung }}=-0,292$ lebih kecil dari pada $r_{\text {tabel }}=0,259$. Korelasi antara bagian pertama dan kedua adalah 0,414 dan Guttman split half adalah 0,529. Hasil koefisien reliabilitas Spearman Brown adalah sebesar 0,586 kemudian hasil tersebut dibandingkan dengan $r_{\text {tabel }}=0,259$ dengan taraf signifikansi 0.05 sehingga $t_{\text {hitung }}=0,586$ lebih besar dari pada $r_{\text {tabel }}=0,259$, dengan demikian instrumen ini memiliki koefisien korelasi reliabilitas pada kriteria sedang.

Peneliti melakukan uji yang selanjutnya menggunakan uji prasyarat yang peneliti gunakan terdiri dari uji normalitas dan uji homogenitas, uji normalitas digunakan peneliti untuk melihat apakah data yang akan dianalisis peneliti terdistribusi normal atau tidak. Data yang terdistribusi normal memiliki nilai signifikansi lebih besar dari 0,05, sedangkan data yang tidak terdistribusi normal memiliki nilai signifikansi lebih kecil dari 0,05. Hasil uji normalitas dan homogenitas dapat menentukan uji hipotesis yang akan digunakan. Hasil uji prasyarat yang telah dilakukan peneliti menunjukkan bahwa data tersebut terdistribusi normal dan homogen. Hal ini sejalan dengan penelitian Siregar (2015: 103) menyatakan bahwa diketahui rata-rata hasil analisis data pretest kedua kelas penelitian menunjukkan nilai rata-rata pretest dan postest kedua kelas terdistribusi normal dan homogen. Sehingga peneliti menggunakan pengujian hipotesis menggunakan 
uji hipotesis parametrik, untuk menguji hipotesis peneliti menggunakan uji independent sample t-test dengan menggunakan aplikasi SPSS versi 20.

Hasil analisis hipotesis dengan menggunakan uji independent sample t-test dengan nilai signifikansi $\alpha=0,05$. Pengambilan keputusan dari hasil perhitungan sig 2 tailed sebesar 0,000, sehingga nilai sig 2-tailed $0,000<\alpha=0,05$ maka dapat disimpulkan bahwa $\mathrm{H}_{0}$ ditolak dan $\mathrm{H}_{\mathrm{a}}$ diterima. Hal ini berarti bahwa terdapat pengaruh HOTS pada peserta didik yang diajarkan menggunakan model pembelajaran kooperatif tipe talking stick dengan yang diajar menggunakan model konvensional. Hal ini selaras dengan (Pangkali , Sinon \& Widyaningsih, 2016: 178) menyatakan bahwa hasil uji independent simple t-test dengan taraf sig $<0,05$ nilai $\mathrm{t}_{\text {hitung }}>\mathrm{t}_{\text {tabel }}$ maka $\mathrm{H}_{0}$ ditolak, maka terdapat perbedaan hasil belajar peserta didik antara kelas kontrol dan kelas eksperimen.

Selain itu, model pembelajaran kooperatif tipe talking stick dan model konvensional juga memiliki pengaruh terhadap HOTS peserta didik dengan besar yang berbeda. Pada saat peneliti memberikan perlakuan kepada peserta didik pada kelas eksperimen dengan menggunakan model pembelajaran kooperatif tipe talking stick dengan bantuan alat peraga sederhana maka terdapat pengaruh yang ditimbulkan peserta didik menjadi lebih aktif dan kreatif pada saat proses pembelajran berlangsung di bandingkan dengan kelas kontrol. Hal ini sejalan dengan penelitian Misnawati (2017: 227) menyatakan bahwa model pembelajaran kooperatif tipe talking stick merupakan pemodelan yang berorientasi pada keterampilan, dimana guru menguraikan materi secara sederhana kepada peserta didik sampai peserta didik benar-benar memahami materi yang telah diajarkan.

Keterampilan berpikir tingkat tinggi (HOTS) sangat diperlukan peserta didik disekolah, hal ini dikarenakan permasalahan-permasalahan higher oder thingking skill (HOTS) dalam kehidupan sesungguhnya yang bersifat rumit dan memerlukan keterampilan berpikir yang dimiliki peserta didik. Hal ini sejalan dengan Riadi \& Retnawati, (2014: 127) menyatakan bahwa higher oder thingking skill (HOTS) sangat diperlukan peserta didik karena permasalahan dalam kehidupan sesungguhnya bersifat kompleks, rumit, baru, dan memiliki keterampilan berpikir yang lebih dari sekedar mengaplikasikan apa yang telah dipelajari.

\section{SIMPULAN DAN SARAN}

\section{Kesimpulan}

Berdasarkan analisis data peneliti menyimpulkan bahwa dari perhitungan menggunakan uji independent sample t-test data hasil belajar dari kelas eksperimen dan kontrol memiliki nilai signifikansi lebih kecil dari $\alpha=0,05$ yang berarti $\mathrm{H}_{0}$ ditolak dan $\mathrm{H}_{\mathrm{a}}$ diterima, sehingga dapat disimpulkan terdapat pengaruh yang signifikan model talking stick terhadap keterampilan berpikir tingkat tinggi (HOTS) pada peserta didik kelas VIIIa. Hasil pengujian hipotesis didukung oleh perhitungan nilai $\mathrm{N}$-gain yang menunjukkan bahwa nilai N-gain untuk kelas eksperimen lebih besar dari pada kelas kontrol, dimana nilai $\mathrm{N}$-gain pada kelas eksperimen 0,39 sedangkan nilai $\mathrm{N}$-gain pada kelas kontrol 0,38. Hasil uji N-gain didukung dengan nilai rata-rata posttest HOTS kelas eksperimen sebesar 75 dan kelas kontrol 45. Sehingga HOTS pada kelas eksperimen lebih tinggi dari kelas kontrol. 


\section{Saran}

Berdasarkan hasil penelitian, maka peneliti memberikan beberapa saran yaitu:

1. Saran kepada pihak sekolah, dapat menggunakan model-model pembelajaran yang menarik agar peserta didik dapat lebih aktif dan hasil belajar peserta didik pun dapat meningkat.

2. Bagi pembaca, semoga hasil penelitian ini dapat menambah wawasan agar dapat memilih model-model pembelajaran yang sesuai.

\section{DAFTAR PUSTAKA}

Arikunto, S. (2013). Dasar-dasar Evaluasi Pendidikan Edisi 2. Jakarta: Bumi Aksara. Arifin, Z. \& Retnawati, H. (2017). Pengembangan Instrumen Pengukur Higher Order Thinking Skills Matematika Siswa SMA Kelas X. Phytagoras: Jurnal Matematika dan Pendidikan Matematika, 12(1) 99-100.

Alpusari, M. (2014). Analisis Butir Soal Konsep Dasar IPA 1 Melalui Penggunaan Program Komputer Anates Versi 4.0 For Windows Pekanbaru, Jurnal Primary Program Studi Pendidikan Guru Sekolah Dasar Fakultas Keguruan dan Ilmu Pendidikan Universitas Riau, 3(2) 110.

Depdiknas. (2007). Peraturan Mentri Pendidikan Nasional RI Nomor 41 Tahun 2007 tentang Standar Proses untuk Satuan Pendidikan 142 Model dan Metode Pembelajaran di Sekolah Sadar dan Menengah. Jakarta: Depdiknas.

Diani, R., Ardian, A., \& Orin, N. J. (2018). Pengaruh Model RMS (Reading, Mind Mapping And Sharing) Terhadap Kemampuan Berpikir Tingkat Tinggi Siswa Pada Pokok Bahasan Impuls dan Momentum. Jurnal Pendidikan Edutama, 5(1) 31-43.

Djamas, D. (2011). Meningkatkan Mutu Pembelajaran Fisika dengan Memberdayakan Critical Thinking Skill, 342-357.

Misrawati. (2017). Peranan Guru BK Dalam Membentuk Karakter Siswa Melalui Layanan BK Kelompok, Pembelajar: Jurnal Ilmu Pendidikan, Keguruan, dan Pembelajaran, 1(2) 65-68.

Misnawati. (2017). Upaya Meningkatkan Hasil Belajar Fisika Melalui Model Pembelajaran Kooperatif Tipe Talking Stick pada Siswa Kelas VIIA SMP Negeri 1 Sinjai Selatan, Jurnal Pendidikan Fisika - Journal of Physics Education, 1(3) 227.

Nurlailah, F., \& Buditjahjanto, I.G.P. (2013). Pengaruh Model Pembelajaran Kooperatif TPS dengan Kecerdasan Logis Matematis terhadap Hasil Belajar Siswa di SMK Negeri 3 Surabaya. Jurnal Pendidikan Teknik Elektro, 2(2) 698-706.

Sanjaya, W. (2008). Strategi Pembelajaran Berorientasi Standar Proses Pendidikan. Jakarta: Kencana Prenada Media Group.

Sugiyono. (2015). Metode Penelitian Pendidikan Pendekatan Kualitatif, Kuantitatif dan $R \& B$. Bandung: Alfabeta.

Siregar, S. (2015). Pengaruh Model Pembelajaran Talking Stick Terhadap Hasil Belajar dan Aktivitas Visual Siswa pada Konsep Sistem Indra. BIOTIK: Jurnal Ilmiah Biologi dan Teknologi Pendidikan, 3(2) 103.

Pangkali, T, Sinon, I. L. S., \& Widyaningsih, S. W. (2016). Penerapan Model Kooperatif Tipe TPS Terhadap Hasil Belajar Kognitif dan Aktivitas Peserta Didik Pada Materi Gelombang Mekanik Kelas XI IPA SMA Negeri 1 Kabupaten Sorong. Jurnal Ilmiah Pendidikan Fisika Al-BiRuNi, 5(2) 178-179. 
Pramesti, G. (2014). Kupas Tuntas Data Penelitian dengan SPSS 22. Jakarta: Elex Media Komputindo.

Rahmawati \& Melisa. (2016). Pengaruh Penerapan Pendekatan Kontekstual Bermedia Power Point Terhadap Hasil Belajar Siswa pada Materi Sistem Ekskresi pada Manusia Kelas VIII SMPN Bireuen. Jurnal Edukasi dan Sains Biologi, 5(1) 3-4.

Riadi, A \& Retnawati, H. (2014). Pengembangan Perangkat Pembelajaran untuk Meningkatkan HOTS pada Kompetensi Bangun Ruang Sisi Datar. PYTHAGORAS: Jurnal Pendidikan Matematika, 9(2) 126-135.

Widyaningsih, S. W. (2011). Pembentukan Karakter Bertanggung Jawab dan Rasa Ingin Tahu Melalui Penerapan Metode Quantum Learning Dengan Menggunakan Media Alat Peraga Sederhana Pada Pembelajaran Fisika, Seminar Nasional MIPA dan Pendidikan MIPA UNP, 297-309.

Yusuf, I., \& Widyaningsih, S. W. (2018). Profil Kemampuan Mahasiswa dalam Menyelesaikan Soal HOTS di Jurusan Pendidikan Fisika Universitas Papua. Jurnal Komunikasi Pendidikan, 2(1) 42-49. 